\title{
THE STUDY OF THE EFFECT OF COMORBIDITIES ON PHARMACOTHERAPY OF PATIENTS WITH LIVER CIRRHOSIS
}

\author{
I.O.Fedyak, O.V.Maksymenko
}

\author{
Ivano-Frankivsk National Medical University
}

Key words: cirrhosis; comorbidity; frequency analysis; VEN analysis; drugs used to treat liver diseases

\begin{abstract}
Recently, the incidence of liver cirrhosis has been increasing and the mortality is still high. The death rate from liver cirrhosis is $2 \%$ of all deaths of the world's population, and mortality is on the 5th place. The subject of the study was 190 medical records of patients diagnosed with liver cirrhosis in the Department of Gastroenterology of Ivano-Frankivsk Regional Clinical Hospital for 2012-2013. According to the analysis of gender, age, social characteristics, the area of residence and comorbidities in 190 patients with LC their generalized portrait has been represented. This is a man aged 51-60, who mostly comes from rural areas (57.4\%), does not work in 66\% of cases and has such comorbidities as chronic pancreatitis (66.3\%), chronic gastroduodenitis (54.2\%), chronic cholecystitis (48.9\%). The results of frequency and formal VEN analyses of medication administration records of the patients indicate that they received substantial treatment of comorbidities (55\% of the drugs prescribed). To optimize the treatment of patients with LC it is necessary, first of all, to develop a new protocol of medical care to patients with LC taking into account the data of evidence-based medicine, pharmacoeconomics and coordination with regulatory lists of drugs. It has been shown that the simultaneous treatment of LC and comorbidities leads to polypharmacy.
\end{abstract}

R ecently, the incidence of li-

Rver cirrhosis (LC) has been increasing and the mortality is still high $[2,10]$. Thus, in 2010 the death rate from LC was more than 1 million of people, it was $2 \%$ of all deaths of the world's population, and mortality was on the 5th place among the causes of death of people after coronary heart disease, cerebrovascular diseases, lung cancer, HIV infection/AIDS. Differences in mortality rates between countries are due to different levels of consumption of alcohol and the prevalence of viral hepatitis C and B. The European average age of death from LC is 59 years compared to $82-84$ years for heart, lung diseases or stroke. Over the past 10 years, 5 -fold increase in cases of LC in patients aged 35-55 was observed $[10,13]$. In Ukraine, the number of patients with LC increased by $9.5 \%$ from 2006 to 2013, and mortality - by $19 \%[7]$.

The therapeutic measures in patients with LC are determined by their etiology, degree of activity and compensation, the presen- ce of complications and comorbidities [1, 2, 4-6, 8, 9-11].

The aim of this study was to rank comorbidities of patients with LC and determine the extent of their influence on prescriptions of doctors by conducting the retrospective methods of clinical and economic analysis of pharmacotherapy.

\section{Materials and Methods}

The object of the study was the work of a particular healthcare institution (HCI) concerning organization of pharmaceutical provision of patients with LC. The subject of the study was 190 medical records of patients diagnosed with liver cirrhosis in the Department of Gastroenterology of Ivano-Frankivsk Regional Clinical Hospital for 2012-2013. Among the medical records $44.2 \%$ belonged to patients with mixed LC, 38.4\% with cryptogenic, $12.1 \%$ - viral, $3.2 \%$ - portal and $2.1 \%$ - biliary LC. A retrospective evaluation of the drugs prescribed was conducted using methods of frequency and formal VEN analysis. Frequen-

I.O.Fedyak - Candidate of Pharmacy (PhD), associate professor of the Organization and Economy in Pharmacy and Drug Technology Department of the Ivano-Frankivsk National Medical University

cy analysis of the therapy made it possible to assess its tendencies since it illustrates the opinions of doctors and the financial possibilities of patients. VEN analysis is distribution of drugs according to the importance of their prescription for the treatment of a particular disease (L.V.Iakovlieva, 2009). This analysis was conducted on formal grounds. Class V included drugs of the basic pharmacotherapy recommended by Protocol 1.14 "Care to Patients with Liver Cirrhosis" according to the Order of the Ministry of Health of Ukraine No. 271 dated 13.06.2005 "On Approval of Protocols of Medical Care in the Specialty of Gastroenterology" (hereinafter referred to as the "Protocol"); class E drugs of adjunctive therapy according to the Protocol; class N - all other drugs prescribed. In addition, group V was analyzed according to belonging of its drugs to the main regulatory lists of drugs in Ukraine, namely: the National List of Basic Drugs and Medical Devices (Resolution of the CMU No. 333 dated 25.03.2009), the Budget List of Drugs (Resolution of the CMU No. 1071 dated 05.09.1996 amended), the National Drug Formulary (NDF) of the $4^{\text {th }}$ ed. (Order 
Table 1

The age and gender distribution of patients with cirrhosis

\begin{tabular}{|c|c|c|c|}
\hline Age & $\begin{array}{c}\text { The number of } \\
\text { patients, including }\end{array}$ & Men & Women \\
\hline $21-30$ & $8(4.2 \%)$ & $5(62.5 \%)$ & $3(37.5 \%)$ \\
\hline $31-40$ & $34(17.9 \%)$ & $20(58.8 \%)$ & $14(41.2 \%)$ \\
\hline $41-50$ & $49(25.8 \%)$ & $34(69.4 \%)$ & $15(30.6 \%)$ \\
\hline $51-60$ & $70(36.9 \%)$ & $52(74.3 \%)$ & $18(25.7 \%)$ \\
\hline $61-70$ & $20(10.5 \%)$ & $13(65 \%)$ & $7(35 \%)$ \\
\hline 71 and more & $9(4.7 \%)$ & $5(55.5 \%)$ & $4(44.5 \%)$ \\
\hline Total & $100 \%$ & - & \\
\hline
\end{tabular}

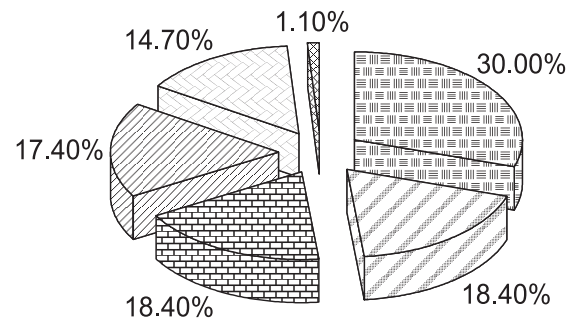

\author{
醇 unemployed \\ persons with disabilities \\ 潩 employees \\ $\bigotimes$ pensioners \\ $\square$ workers \\ participants of military action
}

Fig. 1. Distribution of patients with LC by their social status of the Ministry of Health of Ukraine No. 209 dated 28.02.2012) and the 5 th ed. (Order of the Ministry of Health of Ukraine No. 251 dated 29.03.2013) corresponding to the years of treatment of patients, as well as the 6th ed. (Order of the Ministry of Health of Ukraine No. 252 dated 08.04.2014) and the 7th ed. (Order of the Ministry of Health of Ukraine No. 183 dated 30.03.2015) - for assessment.

\section{Results and Discussion}

The analysis of the inpatient medical records showed that there were $129(67.9 \%)$ men and 61 (32.1\%) women among 190 persons. The data obtained correlate with the literature data that state that men suffer LC 2 times more often than women $[11,12]$. Table 1 shows a detailed gender analysis of patients in age groups with increment of 10 years.

Thus, both men and women aged 51-60 were ill more often. It confirms the tendency towards rejuvenation of persons with LC. The data of other researchers show that the average age of women with LC was $62.4 \pm 8.5$ in 2002, and $59.8 \pm 8.2$ in 2007 [11].

In our sample of medical records spontaneously formed the persons from rural areas dominated $(57.4 \%)$, and urban citizens were $42.6 \%$.

The results of the social status analysis of patients with LC are presented in Fig. 1. It showed that the percentage of unemployed among all patients was about $66 \%$.

In addition to the basic diagnosis, patients had concomitant diagnoses, primarily a few of them.

Table 2
TOP-5 comorbidities in patients with liver cirrhosis

\begin{tabular}{|c|l|c|c|}
\hline No. & \multicolumn{1}{|c|}{ Name of disease } & $\begin{array}{c}\text { Absolute number } \\
\text { of patients }\end{array}$ & $\begin{array}{c}\text { Relative number } \\
\text { of patients, \% }\end{array}$ \\
\hline 1 & Chronic pancreatitis & 126 & 66.3 \\
\hline 2 & Chronic gastroduodenitis & 103 & 54.2 \\
\hline 3 & Chronic cholecystitis & 93 & 48.9 \\
\hline 4 & Biliary dyskinesia & 26 & 13.7 \\
\hline 5 & Diabetes mellitus type II & 22 & 11.6 \\
\hline
\end{tabular}

Table 2 shows the TOP- 5 of comorbidities found in patients with LC.

According to the results of analysis in Table 2 it can be concluded that most comorbidities were related to the hepatobiliary system and belonged to pathologies of the pancreas, liver and biliary tract. There were also few complications of the basic diagnosis in patients with LC.

The next stage of work was to conduct retrospective clinical and economic analyses. As a result of frequency analysis of medication administration records, it was determined that there were 1,968 prescriptions of 197 trade names of drugs to 190 patients with LC (on average 10-11 drugs per a patient). The analysis revealed that the drugs belonged to 12 groups of the ATC classification and 6 items of dietary supplements (DS) (Fig. 2).

The data presented graphically in Fig. 2 show that leaders in ATC groups were the following groups: A - "Drugs that affect the digestive system and metabolism" (46.20\%), $\mathrm{C}$ - "Drugs for the treatment of cardiovascular diseases" (15.23\%), $\mathrm{N}$ - "Drugs to treat diseases of the nervous system" (10.66\%). The wide range of drugs according to ATC suggests that patients received substantial treatment of comorbidities along with the LC therapy. Therefore, both the existence of basic disease complications and the presence of comorbidities significantly increase the number of drug prescriptions.

Table 3 shows the TOP- 10 drugs by the frequency of prescriptions. Analysis of Table 3 shows that the top ten drugs include: 4 hepatoprotectors, 2 diuretic drugs and 1 drug from the groups of lactulose drugs, antiarrhythmic, vitamin $\mathrm{K}$ and proton pump inhibitors. When comparing the drugs prescribed most often in accordance with the requirements of the Protocol it was found that all of them were recommended for medical care to patients with LC.

Overall frequency analysis revealed that 32 hepatoprotectors 


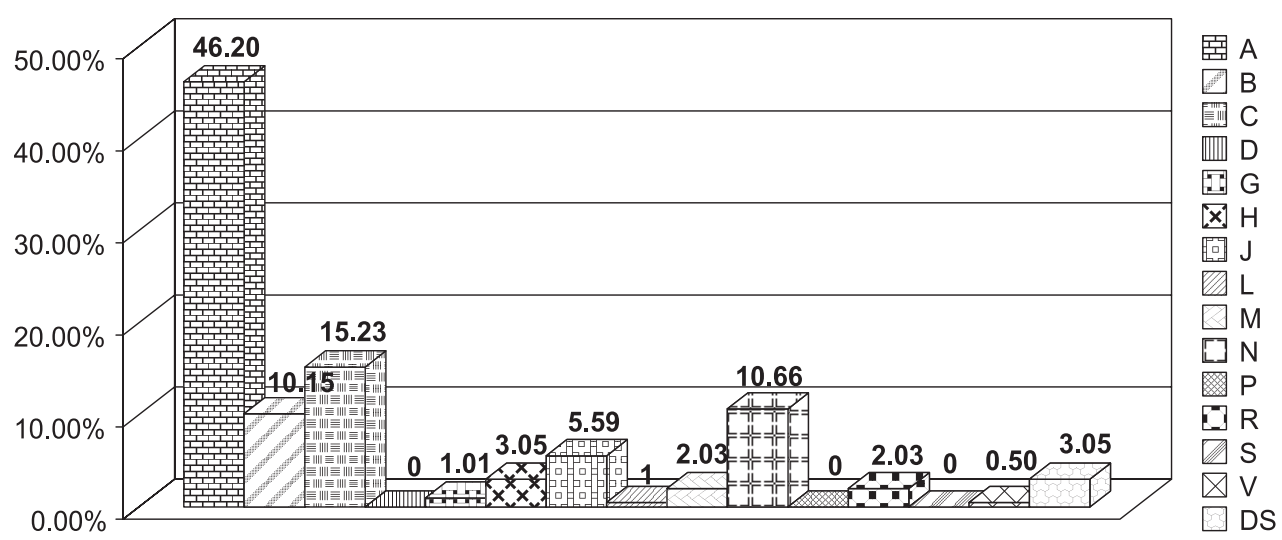

Fig. 2. Consumption of drugs by ATC classification groups

were prescribed to patients; it comprised 565 prescriptions (28.7\%). This is the main group of drugs, along with the causal antiviral therapy, according to the Protocol which divides the drugs on the drugs of basic and adjunctive therapy. The first group, except for hepatoprotectors (including ursodeoxycholic acid and amino acids), includes enzyme, diuretic, antibacterial, $\beta$-blockers, probiotics and infusion drugs. The second one is hormonal preparations for hemostatic therapy, blood products, parenteral proton pump inhibitors and $\mathrm{H}_{2}$ antagonists.

The formal VEN analysis of the consumed drugs was conducted to assess the rationality of prescriptions according to the recommendations of the Protocol (Fig. 3).

Hence, the compliance of the consumed drug therapy with the clinical protocol of medical care to patients with LC can be estimated in $45 \%$ (the amount of percent of drugs of classes $\mathrm{V}$ and $\mathrm{E}$ ). But the Protocol was adopted in 2005. It has not been revised yet. It does not meet modern requirements of medical standardization: it has only general pharmacological groups of drugs, but not INN, and does not contain the recommended doses, presentation and conditions for drug administration.
Therefore, we analyzed the class $\mathrm{V}$ drugs for their presence in the social and economic regulatory lists of drugs in Ukraine. The analysis revealed that from 67 drugs of class V only 15 drugs (diuretics, antibiotics and infusion therapy drugs) were simultaneously included into all basic regulatory lists: the National List of Basic Drugs, Budget List of Drugs and NDF. They were for $22.39 \%$ of the basic therapy drugs. Drugs from the group of hepatoprotectors were not included into the National List of Basic Drugs. Instead, the Budget List contained 59 from 67 the basic drugs prescribed, they were $88.06 \%$. And 55 basic therapy drugs

Table 3

TOP-10 drugs prescribed to patients with liver cirrhosis most often

\begin{tabular}{|c|l|c|c|}
\hline No. & \multicolumn{1}{|c|}{ Name of drug } & $\begin{array}{c}\text { Absolute number } \\
\text { of prescriptions }\end{array}$ & $\begin{array}{c}\text { Relative } \\
\text { number, } \%\end{array}$ \\
\hline 1. & $\begin{array}{l}\text { Verospiron caps., 100 mg, No. 30 } \\
\text { (Gedeon Richter JSC, Hungary) }\end{array}$ & 122 \\
\hline 2. & $\begin{array}{l}\text { Thiogamma Turbo sol. for inf., 1.2\%, No. 1 } \\
\text { (Woerwag Pharma GmbH \& Co. KG, Germany) }\end{array}$ & 87.20 \\
\hline 3 & $\begin{array}{l}\text { Duphalac syrup, 667 g / 1000 ml, 500 ml } \\
\text { (Solvay Pharmaceuticals/ Abbott Biologicals BV, The Netherlands) }\end{array}$ & 78 & 3.42 \\
\hline 4 & $\begin{array}{l}\text { Heptral lyoph. pwd. for sol. for inj., 400 mg, No. 5 } \\
\text { (Hospira SP / Famar Lyehl, Italy / France / Greece) }\end{array}$ & 68 \\
\hline 5 & $\begin{array}{l}\text { Glutargin conc. for sol. for inf., 40\%, 5 ml, No. 10 } \\
\text { ("Zdorovye" Pharmaceutical Company, Ukraine) }\end{array}$ & 68 & 3.45 \\
\hline 6 & Asparcam tab., No. 50 (Galychpharm JSC, Urkaine) & 56 \\
\hline 7 & $\begin{array}{l}\text { Essentiale sol. for inj., 250 mg / 5 ml, No. 5 } \\
\text { (Ed. Nattermannend Sayi HmbH, Germany) }\end{array}$ & 53 & 2.85 \\
\hline 8 & $\begin{array}{l}\text { Furosemide sol for inj., 10 mg / ml, 2 ml, No. 10 } \\
\text { ("Darnitsa" Pharmaceutical company, Ukraine) }\end{array}$ & 2.69 \\
\hline 9 & $\begin{array}{l}\text { Vicasol sol. for inj., 1\%, 1 ml, No. 10 } \\
\text { ("Darnitsa" Pharmaceutical company, Ukraine) }\end{array}$ & 51 & 2.59 \\
\hline 10 & $\begin{array}{l}\text { Controloc tab., resist. gastr., 40 mg, No. 28 } \\
\text { (AltanaPharma AG, Germany) }\end{array}$ & 34 & 1.72 \\
\hline
\end{tabular}




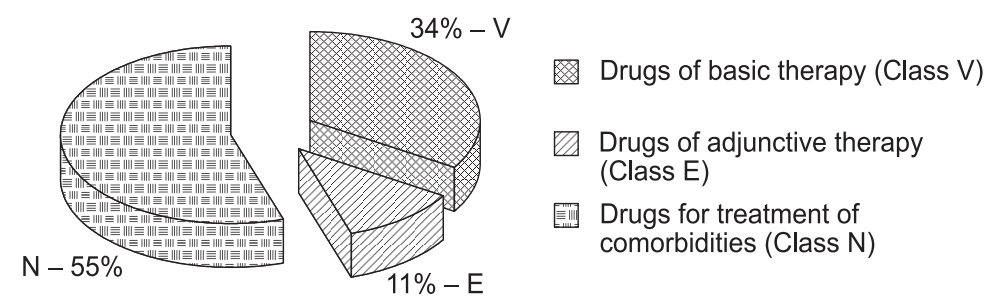

Fig. 3. The results of the formal VEN analysis for the therapy consumed by the patients with LC

were included in the NDF of the $4^{\text {th }}(2012)$ and $5^{\text {th }}(2013)$ editions. However, the NDF of the $6^{\text {th }}$ edition (2014) limited a number of groups of hepatoprotectors (48 basic therapy drugs $-71.64 \%$ ), and only ursodeoxycholic acid drugs, silymarin and amino acids remained in the NDF of the $7^{\text {th }}$ edition (2015) (44 basic therapy drugs - 65.67\%).

At the same time in the TOP-10 drugs (see Table 3) Thiogamma Turbo (Woerwag Pharma GmbH \& Co. KG, Germany), Glutargin (Zdorovye, Ukraine) and Essentiale (Ed. Nattermannend Sayi $\mathrm{HmbH}$, Germany), which were no longer formulary drugs according to the NDF of the $7^{\text {th }}$ edition since April 2015, took the $2^{\text {nd }}, 5^{\text {th }}$ and $7^{\text {th }}$ rating positions, respectively. Among the 4 most common hepatoprotectors, only Heptral (Hospira SP / FamarLyehl, Greece) was included in the last updated NDF. This fact shows the need to increase the motivation of physicians to a permanent treatment to use in their work the recommendations of the updated editions of the NDF of Ukraine.

Therefore, to optimize the treatment of patients with LC it is necessary, first of all, even not to revise it, but develop a new protocol of medical care to patients with LC taking into account the data of evidence-based medicine, pharmacoeconomics and coordination with regulatory lists of drugs, which also should be based on generally accepted approaches, namely evidence and economic feasibility.

At the same time treatment of patients with LC according to the US and UK Clinical Guidelines [3, $5]$ is not overloaded with drugs, and focuses on the lifestyle of the patient and pharmaceutical care. Here we see the main role of pharmacists in overcoming the problem of chronic liver diseases in ge- neral, and LC in particular. As the simultaneous treatment of patients with LC and comorbidities is the negative practice, it leads to polypharmacy being unacceptable in LC.

\section{CONCLUSIONS}

According to the analysis of gender, age, social characteristics, the area of residence and comorbidities in 190 patients with LC their generalized portrait can be represented. This is a man aged 51-60, who mostly comes from rural areas (57.4\%), does not work in $66 \%$ of cases and has such comorbidities as chronic pancreatitis (66.3\%), chronic gastroduodenitis (54.2\%), chronic cholecystitis (48.9\%).

The results of frequency and formal VEN analyses of medication administration records of the patients indicate that they received substantial treatment of comorbidities (55\% of the drugs prescribed). Therefore, we consider it appropriate to recommend adherence to the formulary approach to inpatient treatment: first treat the underlying disease determining it by the risk value, and then proceed to the treatment of comorbidity. There is also a need to develop a new clinical protocol of medical care to patients with liver cirrhosis in Ukraine.

\section{REFERENCES}

1. Abragamovych M.O., Farmaga M.L. // Lviv Clinical Herald. - 2013. - №2. - P. 37-45.

2. Babak O.Ya., Harchenko N.V. Rational diagnostics and pharmacotherapy of the digestive system diseases: Doctor's reference Gastroenterologist. - Kiev: "Doctor-Media", 2007. - 308 p.

3. Bruce A. Runyon // Hepatol. - 2013. - Vol. 57. - P. 1651-1653.

4. Cirrhosis [Electronic resource] / Verneda Lights, Jennifer Nelson // Medically Reviewed Publishedon. 2012. - Access mode : http://www.healthline.com/health/cirrhosis.

5. Detlef Schuppan, Nezam H. Afdhal // Lancet. - 2008. - Vol. 371. - P. 838-851.

6. Eric Gershwin M., Selmi C., Worman H.J. et al. // Hepatol. - 2005. - Vol. 42. - P. 1194-1202.

7. Fedyak I.O., Maksymenko O.V. Urgency use pharmacoeconomic approach to optimize the treatment of patients with cirrhosis [Text] // Pharmacoeconomics in Ukraine: state and prospects of development of materials science and practical VI. Conf. - Kh., 2013. - P. 246-247.

8. Jepsen P. // World J. Gastroenterol. - 2014. - Vol. 20 (23). - P. 7223-7230. [Electronic resource] - Access mode: http://www.wjgnet.com/1007-9327/full/v20/i23/7223.htm.

9. Jepsen P., Vilstrup H., P. Kragh Andersen et al. // Hepatol. - 2008. - Vol. 48. - P. 214-220.

10. Mokdad Al., Lopez Al.D., Shahraz S. et al. Liver cirrhosis mortality in 187 countries between 1980 and 2010: a systematic analysis // BMC Medicine. - 2014. [Electronic resource] - Access mode : http://www. biomedcentral.com/1741-7015/12/145. 
11. Samogalska O.Ye., Karpenko N.V. // Herald of Sci. Res. - 2008. - №2. - P. 19-21.

12. Tkacheva O.V., Minova K.O. Frequency analysis of drugs for the treatment of liver cirrhosis in hospital in Kharkiv [Text] // Pharmacoeconomics in Ukraine: state and prospects of development of materials science VI -pract. conf. - Kh., 2014. - P. 55-56.

13. Williams R., Aspinall R., Bellis M. et al. // The Lancet. - 2014. - Vol. 384, №9958. - P. 1953-1997. [Electronic resource]-Access mode: http://www.thelancet.com/pdfs/journals/lancet/PIIS0140-6736(14)61838-9.pdf.

\title{
ВИВЧЕННЯ ВПЛИВУ СУПУТНІХ ЗАХВОРЮВАНЬ НА ФАРМАКОТЕРАПІЮ ХВОРИХ НА ЦИРОЗИ ПЕЧІНКИ
}

І.О.Федяк, О.В.Максименко

Івано-Франківський національний медччний університет

Ключові слова: цирози печінки; супутнє захворювання; частотний аналіз; VЕN-аналіз; лікарські засоби для лікування захворювань печінки

У світі зростає захворюваність на цирози печінки (ЦП), а летальність залишається високою: рівень смертності від ЦП складає 2\% від усіх смертей населення планети, а летальність є п'ятою причиною смерті людей. Предметом дослідження були 190 медичних карт хворих гастроентерологічного відділення Івано-Франківської обласної клінічної лікарні за 2012-2013 рр. із діагнозом ЦП. За результатом аналізу гендерних, вікових, соціальних ознак, місцевості проживання, наявності супутніх хвороб у пацієнтів досліджуваної спонтанної вибірки представлено їх узагальнений портрет. Це переважно чоловік 51-60 років, який здебільшого походить із сільської місцевості (57,4\%), у 66\% випадків не пращює та має супутні захворювання: хронічний панкреатит (66,3\%), хронічний гастродуоденіт (54,2\%), хронічний холецистит (48,9\%). Результати частотного та формального VEN-аналізів листків призначень пацієнтів свідчать, що вони отримали значне лікування супутніх хвороб (55\% призначених препаратів). Для оптимізації лікування цієї категорії пацієнтів насамперед необхідно поновити Протокол медичної допомоги хворих на ЦП (наказ МОз України №271 від 13.06.2005 р.) із врахуванням даних доказової медицини, фармакоекономіки та узгодженням із регулюючими переліками лікарських засобів в Україні. Показано, що одночасне лікування хворих на ЦП та супутні захворювання призводить до поліпрагмазії.

\section{ИЗУЧЕНИЕ ВЛИЯНИЯ СОПУТСТВУЮЩИХ ЗАБОЛЕВАНИЙ НА ФАРМАКОТЕРАПИЮ БОЛЬНЫХ НА ЦИРРОЗЫ ПЕЧЕНИ}

\section{И.О.Федяк, А.В.Максименко}

Ивано-Франковский национальный медицинский университет

Ключевые слова: циррозы печени; сопутствующее заболевание; частотный анализ; VEN-анализ; лекарственные средства для лечения заболеваний печени

\begin{abstract}
В мире растет заболеваемость на циррозы печени (ЦП), и остается высокой их летальность: уровень смертности от ЦП составляет 2\% всех смертей населения планеты, а летальность является пятой причиной смерти людей. Предмет исследования - 190 медицинских карт больных гастроэнтерологического отделения Ивано-Франковской областной клинической больницы за 2012-2013 гг. с диагнозом ЦП. По результатам анализа гендерных, возрастных, социальных признаков, местности проживания, наличия сопутствующих болезней у пациентов исследуемой спонтанной выборки представлен их обобщенный портрет. Это преимущественно мужчина 51-60 лет, который в основном происходит из сельской местности (57,4\%), в 66\% случаев он не работает и имеет сопутствующие заболевания: хронический панкреатит (66,3\%), хронический гастродуоденит (54,2\%), хронический холещистит (48,9\%). Результаты частотного и формального VEN-анализов листов назначений пациентов указывают, что 55\% выписанных им препаратов были для лечения сопутствующих болезней. Для оптимизации фармакотерапии этой категории пациентов, в первую очередь, необходимо обновить Протокол медицинской помощи больных ЦП (приказ МЗ Украины №271 от 13.06.2005) с учетом данных доказательной медицины, фармакоэкономики и согласования с регулирующими перечнями лекарственных средств в Украине. Показано, что одновременное лечение ЦП и сопутствующих болезней ведет к полипрагмазии.
\end{abstract}

Address for correspondence:

Received in 13.04.2016

2, Halytska str., Ivano-Frankivsk, 76000.

Тел. (97) 951-39-54. E-mail: irynaf@tvnet.if.ua.

Ivano-Frankivsk National University 